\title{
DIALOG ANTAR UMAT BERAGAMA DALAM \\ MENANGGULANGI KONFLIK
}

\author{
Aliyandi A.Lumbu \\ Institut Agama Islam Negeri (IAIN) Metro \\ Jl. Ki Hadjar Dewantara 15 A Kota Metro Lampung 34111
}

\begin{abstract}
Abstrack
The main problem of the people who use religion as a relatively dominant system of reference values as found in the past is that the community's ability to find certain social mechanisms, both naturally and planned, can guarantee legal and social order. One form of planned social mechanism has been carried out by the government through the development of harmony politics, such as encouraging the formation of religious religious assemblies, developing understanding among leaders and religious leaders through various meetings and personal contacts.

Religion is not only heard from the call to prayer that radiates from the minarets of mosques all over the world, the loud bells of the church and the curry of the holy services, but also echoes in congressional forums, conferences, discussion seminars, symposiums, gatherings, recitations, and so on. Print and electronic media are increasingly productive in voicing religious issues.

The conflicts that have occurred or often occur among the people are; conflicts between religious communities, internal religious conflicts and conflicts outside religious affairs. From here the role of the Institute for Religious Harmony is very important for conducting dialogue between religious communities, to minimize or even avoid conflicts that occur among the community.
\end{abstract}

Key word: dialogue, religious people, and conflict prevention 


\section{A. PENDAHULUAN}

Kenyataan empiris di Lampung akhir-akhir ini menunjukkan bahwa aksi kekerasan di tengah masyarakat melibatkan simbol simbol agama. Perusakan harta benda seperti rumah, tempat ibadah atau penodaan kegiatan ritual keagamaan, sering terjadi di sejumlah tempat di tanah air. Agama, secara kasat mata telah "digunakan" para pemeluknya sebagai sekat pemisah yang signifikan terhadap pemeluk agama lain. Secara lebih teoritis, agama seringkali diposisikan salah satu sistem acuan nilai (systems of referenced volues) dalam keseluruhan sistem tindakkan (system of action) yang mengarahkan dan menentukkan sikap dan tindakkan umat beragama.

Problem utama masyarakat yang menggunakan agama sebagai sistem acuan nilai yang relatif dominan seperti yang ditemukkan dilampung, terletak pada kemampuan masyarakat tersebut menemukan mekanisme sosial tertentu, baik secara alamiah maupun terencana, yang dapat menjamin tertib hukum dan sosial. Salah satu bentuk mekanisme sosial yang diusahakan secara terencana, telah dilakukan pemerintah melalui pengembangan politik kerukunan, seperti mendorong terbentuknya majelis agama agama, mengembangkan kesepahaman diantara para pemimpin dan tokoh agama melalui berbagai pertemuan dan kontak pribadi, serta mengembangkan perangkat peraturan yang berfungsi mencegah kemungkinan timbulnya penggunaan agama sebagai sistem acuan hingga ketingkat konflik.

Sementara itu, bentuk mekanisme sosial yang secara alamiah dikembangkan sendiri oleh umat beragama, telah mulai banyak dikenal melalui studi studi khusus untuk itu. Beberapa kasus kerukunan umat beragama yang berkembang ditengah masyarakat sebagai hasil prakarsa mayarakat sendiri, telah sering diteliti Kerukunan Umat Beragama (KUB), melalui Humas Kementrian Agama Provinsi Lampung.

Dalam masyarakat yang majemuk ini, terdapat klaim kebenaran (truth claim) dan watak missioner dari setiap agama, membuka peluang terjadinya benturan dan kesalah pengertian bagi penganut agama. Hal ini jelas dapat mengakibatkan retaknya hubungan antar umat beragama. Disini letak pentingnya diselenggarakan dialog antar agama. ${ }^{1}$

Dialog yang dimaksud disini bukan berdebat tentunya, adu argumentasi antar berbagai pemeluk agama, sehingga ada yang menang dan ada yang kalah. Dialog agama mengutif A. Mukti Ali, justru membiarkan hak setiap orang menunaikan keyakinan dan menyampaikannya kepada orang lain. Dialog antar agama adalah pertemuan hati dan fikiran antar pemeluk berbagai agama yang bertujuan mencapai kebenaran dalam masalah masalah yang dihadapi bersama. ${ }^{2}$

${ }^{1}$ Imam Ahmad, “Agama Dan Tantangan Zaman," Prisma Jakarta 1084, t.t. h. 22

2 Mukti Ali, Ilmu Perbandingan Agama di Indonesia (Bandung: Mizan, 1993). h. 71 
Tidak dapat dipungkiri bahwa semangat apologetik ini dilatar belakangi oleh besarnya semangat dakwah atau misi dari kaum muslim. Dakwah dan misi ini tidak hanya semata mata diartikan untuk meningkatkan taraf hidup manusia beragama, tetapi juga menyampaian adalah untuk agama yang diyakini kepada penganut agama lain dengan harapan penganut agama lain mengkonvensikan keyakinannya. Pada titik inilah, letak misi para juru dakwah dan lembaga pendidikkan agama. ${ }^{3}$

Dalam Islam sendiri dialog antar umat beragama sesungguhnya bukan hal yang baru, Rasulullah sendiri pada masanya kerap mengutus utusannya untuk mengajak kaum non muslim masuk Islam. Apabila kita perhatikan AlQuran dan sunnah, maka sesungguhnya kita akan mengetahui bahwa dakwah menduduki tempat dan posisi utama, sentral dan menentukan. Keindahan dan kesesuaian Islam dengan perkembangan zaman, baik dalam sejarah maupun dalam praktiknya, sangat ditentukan oleh kegiatan dakwah yang dilakukan oleh umat pada masanya. ${ }^{4}$

Materi dakwah maupun metode yang tidak tepat, sering memberikan gambaran (image) dan persepsi yang keliru tentang islam. Demikian pula kesalahpahaman tentang makna dakwah, menyebabkan salah langkah dalam oprasional dakwah. Sehingga sering tidak membawa perubahan apa-apa, padahal tujuan dakwah adalah untuk memberikan perubahan kepada masyarakat sasaran dakwah kearah kehidupan yang lebih baik.

\section{B. HUBUNGAN ANTAR AGAMA DI INDONESIA}

Agama tidak hanya terdengar dari kumandang adzan yang terpancar dari menara-menara masjid seluruh dunia, nyaringnya lonceng gereja dan kur-kur kebaktian suci, tapi juga bergema di forum-forum kongres, koferensi, seminar diskusi, simposium, sarasehan, pengajian,dan sebagainya. Media cetak dan elektronik semakin produktif menyuarakan isu-isu keagamaan. Maka terlihatlah, bahwa perubahan dunia saat ini bukan saja didominasi oleh ilmu pengetahuan dan teknologi, melainkan juga oleh perkembangan serta peningkatan kesadaran dan pengalaman agama. ${ }^{5}$

Hubungan antar berbagai agama ini berfariasi. Antara Hindu, Budha terjalin hubungan yang harmonis, begitu juga hubungan antara keduanya dengan Islam. Islam, Katolik, dan Protestan, mewarisi hubungan sejarah yang tidak menggembirakan. Sebelum masuk ke Indonesia, mereka telah terlibat dalam hubungan pertentangan dan konflik, eksklusivisme intoleran. Secara iman dan moral masing-masing terpanggil untuk menanamkan dominasi

\footnotetext{
${ }^{3}$ Satrio Pinandito, penerj., Islam Agama protes (Jakarta: Pustaka Hidayah, 1993).h. 61

4 Adi Sasono dan Didin Hafiduddin, Solusi Islam Atas Problem Umat (Ekonomi Pendidikan dan Dakwah) (Jakarta: Gema Insani Press, 1998).h. 175

5 Munwar Ahmad Anees, Syed Z.Abedin, dan Ziauddin Sardar, Dialog Muslim Kristen,Dulu sekarang Dan Esok (Yogyakarta: Al-Qolam, t.t.).h.79
} 
kebenaran dan keselamatan mutlak, yang diyakini masing-masing atas kesesatan dan kecelakaan fatal, yang dianggap berada dipihak lain.

\section{Pluralisme Agama dan Konflik Antar Umat beragama}

Dalam kehidupan bangsa indonesia yang merupakan masyarkat plural, baik dan aspek suku, budaya, bahasa, maupun agama. Pluralitas masyarakatnya unik dalam arti penduduknya memeluk agama-agama besar dunia: Islam, Kristen, Katolik, Hindu dan Budha. Yang pertama datang adalah hindu dan Budha, kemudian datang Islam dan terkahir Kristen dan Katolik. Islam adalah agama yang dipeluk mayoritas masyarakat Indonesia. Menurut sensus tahun 1995 secara nasional,bahwa persentase Pemeluk agama yaitu : islam $(87,21 \%)$ sedang sisinya adalah Kristen, Katolik, Hindu dan Budha.

Dengan adanya pluralisme agama, jelas berarti toleransi keagamaan menjadi sangat penting karena perbedaan-perbedaan dan perpecahan antar kelompok keagamaan dapat memicu konflik, yang pada gilirannya dapat menyebabkan disintegrasi nasional. Karena, pada mulanya hubungan antara masyarakat yang berbeda-beda agama tersebut dapat harmonis, tapi di era reformasi ini terjadi perubahan dalam hubungan tersebut, khususnya antara Islam dan Kristen (Protestan dan Katolik). Diduga faktor penyebabanya antara lain, karena agama Kristen dan agama Islam adalah sama-sama agama misi. ${ }^{6}$

Pemahaman tentang konflik antar umat beragama, perlu diawali dan mengerti bahwa masyarakat Indonesia merupakan bangsa besar dengan corak yang plural. Paradigma keragaman masyarakat itu sebagaimana terungkap dalam formulasi wawasan kebangsaan "Bhineka Tunggal Ika" (unity in diversity) terdiri dan berbagai daerah, etnis, kepulauan yang memiliki akar historik, sistem kepercayaan, bahasa dan cara pandang keagamaan (Religious world-view) yang cukup kompleks. Citra pluralisme dalam masyarakat bangsa secara faktual akademik juga diakui oleh sosiolog dan anntopolog parexlellence,mildred Geertz. ${ }^{7}$

Pluralitas agama yang merupakan bagian dan sistem nilai memiliki potensi integratif didalam membentuk solidaritas komunal dan nasional sebagai entry pointlestarinya kehidupan sosial masyarakat bangsa. Pada posisi lain, pluralitas juga syarat dengan muatan konflik yang mengarah pada teciptanya disintegrasi bangsa. Sebenarnya, suasana sosial masyarakat majemuk ditambah dengan klaim kebenaran (truth claim) dan watak misioner (dakwah) dan setiap agama membuka peluang lebar bisa terjadinya benturan dan kesalahan antar umat beragama. ${ }^{8}$

${ }^{6}$ Muhammad Tholehah Hasan, Kerukunan Hidup umat Beragama, Proyek Kerukunan Hidup Umat Beragama (Jakarta: depag RI, 1997).h.77

7 Faisal Ismail, wawasan Pokok Fikiran Islam, Tentang Islam dan Umatnya (Jakarta: Raja Wali Press, t.t.).h. 2

${ }^{8}$ Arif Subhan, Agama dan Tantangan Zaman (Jakarta: Prisma, 1998).h.364 


\section{Agama Antar Dominasi dan Toleransi}

Dari segi etnografis tidak ada satu kelompok manusiapun diseluruh dunia yang tidak mempunyai kepercayaan, bagaimanapun sederhananya masyarakat memilik kepercayaan itu sendiri. Karena itu juga agama atau kepercayaan merupakan lembaga yang tertua dalam sejarah dunia yang melibatkan diri jauh ke dalam persoalan masyarakat.

Agama yang berfungsi sebagai proses integrasi yaitu masalah transformasi loyalitas dan transformasi identitas dengan bertolak dari sejarah kita dan pendekatan masalah dari segi sosio-etnologis. Masyarakat bangsa kita terdiri dari 300 kelompok suku dengan 250 jenis bahasa dan dialek, tersebar diseluruh kawasan di nusantara. ${ }^{9}$

\section{c. Islam Dan Pluralisme Agama}

Islam sebagai agama samawi, melekatkan dasar-dasar teologidan ajaranajaran yang telah diuji cobakan oleh pembawanya sendiri (Nabi Muhammad SAW) dan berhasil meletakkan pengalaman sosial yang menjunjung tinggi prinsip kemanusiaan dan hak asasinya, ditengah-tengah kehidupan masyarakat majemuk. Prestasi yang seharusnya dipertahankan tersebut mengalami pasang surut ${ }^{10}$, bukan karena kelemahan dan kesalahanteologi atau ajaran islam,tetapi karena faktor-faktorlain seperti :

1. Agama dakam kehidupan masyarkat majemuk dapat berperan sebagai faktor pemersatu (integratif) namun dapat juga berperan sebagai paktor pemecah (disintegratif). Fenomena ini banyak ditentukan oleh empat

2. Lingkungan sosio kultural yang mengelilinginya,dan

3. Peranan dan pengaruh pemuka agama tersebut dalam mengarahkan pengikutnya. ${ }^{11}$

Untuk masalah yang menyangkut pluralisme agama. Al-qur'an dan Sunnah Nabi Muhammad SAW, memberikan bimbingan dan telah implementatif kepada para pengikutnya, mulai dari kehidupan keluarga sampai kepada kehidupan berbangsa dan bernegara, bahkan pemerintahan atau negara pertama yang didirikan oleh Rosul bersama penikutnya di Madinah adalah sebuah Negara dengan kemajemukan agama dan suku.

Rambu- rambu kerukunan dalam kehidupan beragama pada masyarakat majemuk, antara lain dikemukakan dalam al-qur'an surat Al-Hujurat ayat 1112 ;

9 J.Garang, Agama dan Tantangan Zaman (Jakarta: LP3ES IKAPI, 1985).h.148

10 Ilyas Ba-Yunus dan Farid Ahmad, sosiologi dan masyarakat kontemporer (Bandung: Mizan, 1993).h.59

11 Muhammad Thohlan Hasan, Islam dalam perspektif sosio kultural (Jakarta: Lantabora Press, 2000).h. 256 


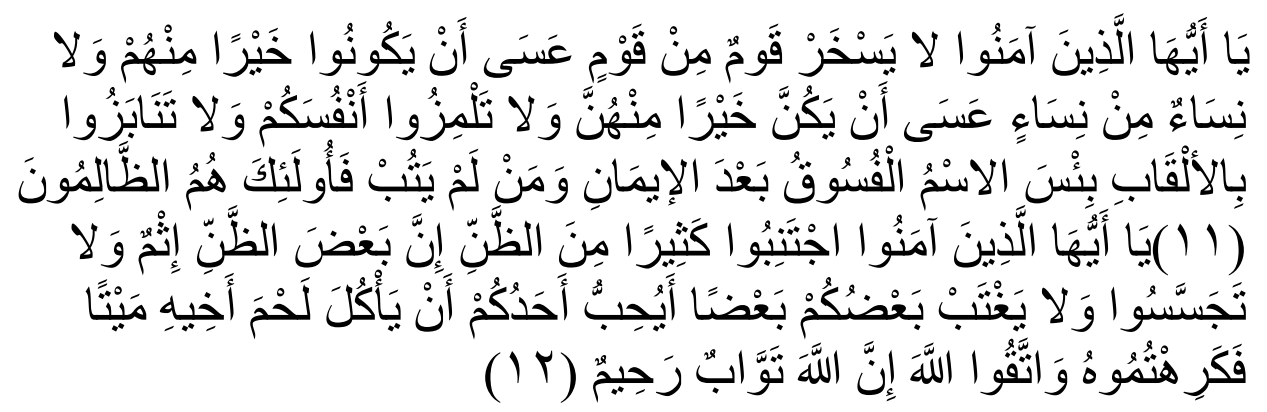

"Hai orang-orang yang beriman, janganlah sekumpulan orang laki-laki merendahkan kumpulan yang lain, boleh Jadi yang ditertawakan itu lebih baik dari mereka. dan jangan pula sekumpulan perempuan merendahkan kumpulan lainnya, boleh Jadi yang direndahkan itu lebih baik. dan janganlah suka mencela dirimu sendiri12 dan jangan memanggil dengan gelaran yang mengandung ejekan. seburuk-buruk panggilan adalah (panggilan) yang buruk sesudah iman ${ }^{13}$ dan Barangsiapa yang tidak bertobat, Maka mereka Itulah orang-orang yang zalim. Hai orang-orang yang beriman, jauhilah kebanyakan purba-sangka (kecurigaan), karena sebagian dari purba-sangka itu dosa. dan janganlah mencari-cari keburukan orang dan janganlah menggunjingkan satu sama lain. Adakah seorang diantara kamu yang suka memakan daging saudaranya yang sudah mati? Maka tentulah kamu merasa jijik kepadanya. dan bertakwalah kepada Allah. Sesungguhnya Allah Maha Penerima taubat lagi Maha Penyayang." 14

Secara filosofi dapat dinyatakan, bahwa pluralisme agama dan integrasi bangsa yang memiliki kemajemukan dapat dijaga keutuhannya, bukan hanya karena masalah teologis dan anjuan agama yang ada, tetapi lebih dari itu adalah terletak pada sikap dan perilaku masyarakatnya yang dipengaruhi cara pemahaman dan penghayatannya terhadap agama yang dianutnya, kemudian pengaru dan peranan para pemuka agama dalam membimbing dan mengarahakan umatnya, serta tidak kalah pentingnya adlah kondisi dan realitas sosio- kultural yang mengelilinginya.

Ajakan untuk mengembangkan kesadaran dan semangat ukhuwah, baik dalam kapasitas "Ukhuwah Islamiyah" (sesama umat islam), maupun "'Ukhuwah Wathoniyah", (antar unat beragama) dan "Ukhuwah Basyariyah" (antar sesama umat beragama), perlu direfleksikan dalam tindak lanjut

\footnotetext{
12 Jangan mencela dirimu sendiri Maksudnya ialah mencela antara sesama mukmin karana orang-orang mukmin seperti satu tubuh.

13 Panggilan yang buruk ialah gelar yang tidak disukai oleh orang yang digelari, seperti panggilan kepada orang yang sudah beriman, dengan panggilan seperti: Hai fasik, Hai kafir dan sebagainya.
}

14 Kementerian Agama Republik Indonesia, Al-Kamal Al-Qur'an Tajwid Warna, Transletirasi Per Kata, Terjemah Per Kata (Jakarta Pusat: Pustaka jaya Ilmu, 2016). h. 517 
secara dinamis dan kesinambungan, dalam rangka mewujudkan kebijakan yang telah ditetapkan bersama dalam pembangunan dan pembinaan kehidupan beragama.

\section{d. Dialog Antar Agama Dalam Menanggulangi Konflik}

Konflik dalam kenyataan dimasyarakat merupakan dinamika kehidupan anggota dan kelompok masyarakat. Karena itu, Lewis A.Coser dalam Margaret M. Polma, mengemukakan bahwa konflik sebagai kesadaran yang tecermin dalam semangat pembaharuan masyarakat. Pandangan ini dapat di pahami bahwa, konflik tidak semata-mata besifat destruktif atau patologis (berdampak negatif) bagi kelompok masyarakat, tetap jugamengandung nilai-nilai positif. Konflik merupakan proses yang bersifat intrumental dalam pembentukan, penyusunan, dan pemeliharaan struktur sosial. Konflik dapat menetapakan dan menjaga garis batas antara dua kelompok atau lebih. Begitu pula konflik dengan kelompok lain (out group) dapat memperkuat kembali identitas kelompok (in group) dan melindunginya agar tidak lebur dalam dunia sosial sekelilingnya.

Nasikun mengklasifikasikan konflik dalam dua bentuk. Pertama, konflik dalam tingkatan yang bersifat idiologis, dan kedua konflik dalam tingkatan yang bersifat politis. ${ }^{15}$ Dalam membahas berbagai situasi konflik, coser membedakan konflik yang realitas dan konflik yang tidak realitas. Konflik yang realitas berasal dari kekacauan terhadap tuntutan-tuntutan khusus, terjadi dalam hubungan dan dari fikiran kemungkinan keutuhan para partisipan yang ditunjukan oleh objek yang mengecewakan, seperti pemogokan karyawan dalam melawan menejemen yang berkuasa. Dipihak lain konflik yang tidak realistik adalah konflik yang bukan berasal dari tujuan-tujuan saingan yang antagonis akan tetapi dari kebutuhan untuk meredakan ketegangan, paling tidak dari salah satu pihak.coser juga membedakan conflik in group dan conflik out group. Conflik in group terjadi tanpa perantara individu dan kelompok dan konflik out group terjadi antara kelompok yang satu dengan kelompok yang lain ${ }^{16}$.

Soerjono soekanto membagi konflik dalam beberapa bentuk, yaitu:

1) Pertentangan pribadi. Tidak jarang bahwa dua orang sejak berkenalan saling tidak menyukai. Apabila permulaan yang buruk tadi di kembangkan ,maka timbul rasa saling membenci dimna masing-masing berusaha saling memusnakan pihak lain.

15 Pada tingkatan yang bersifat idiologis, konflik berwujud dalam bentuk sistem nilai yang dianut strata serta menjadi idiologi berbagai kesatuan sosial. Pada tingkat ini, konflik lebih mudah disimak dalam bentuk perbedaan -perbedaan pengertian dasar diantara berbagai maca golongan masyarakat mengenai beberapa hal. Seperti contoh konflik antar umat beragama,muslim kristen.

${ }^{16}$ Soleman B Taneko, Konsepsi Sistem Sosial dan Sistem di Indonesia (Jakarta: Fajar Agung, 1986).h.55 
2) Pertentangan rasial. Antara individu menyadai bahwa perbedaanperbedaan yang sering kali menimbulkan pertentangan, seperti warna kulit dan ciri-ciri lainnya. Lebih dari itu perbedaan bukan hanya terletak dari segi jasmaniyah saja, melainkan juga perbedaan kepentingan dan kebudayaan atau kenyataan bahwa salah satu ras merupakan golongan mayoritas.

3) Pertentangan antara kelas-kelas sosial. Pertentangan ini terjadi disebabkan karena adanya perbedaan kepentigan, seperti perbedaan kepentingan antara majikan dan buruh

4) Pertentangan politik. Pertentangan antara golongan-golongan dalam satu masyarakat, maupun pertentangan antara suatu negara yang berdaulat

5) Pertentangan yang bersifat internasional. ${ }^{17}$ Terjadi disebabkan oleh perbedaan-perbedaan kepentingan yang kemudian menyangkut kedaulatan negara-negara yang saling bertentangan. Mengalah berarti mengurangi kedaulatan. Dan hal itu berarti kehilangan muka dalam forum internaisonal. Tidak jarang pertentangan itu menimbulkan perang total antara negara-negara tersebut.

\section{Sebab-sebab terjadinya konflik}

Adanya beberapa faktor yang menyebabkan terjadinya konflik, antara lain:

1. Perbedaan kepentingan

Kepentingan merupakan dasar timbulnya tingkah laku individu. Individu bertingkah laku karena adanya dorongan untuk memenuhi kepetingannya. Kepentingan ini sifatnyaesensial bagi kepentingan hidup individu itu sendiri. Jika individu berhasil dalam memenuhi kepentingan, maka ia akan merasa puas dan sebaliknya kegagalan dalam memenuhi kepentingan akan banyak menimbulkan masalah,baik dirinya maupun masyarakat.

Dengan berpegang pada prinsip bahwa tingkah laku individu merupakan cara atau alat dalam memenuhi kepentingannya, maka kegiatan -kegiatan yang dilakukan oleh individu didalam masyarakat pada hakekatnya merupakan manifestasi pemenuhan kepentingan tersebut.

Loepold Van W Howard Becker, berpendapat bahwa akan konflik adalah:

1. Perbedaan antar orang perorangan

2. Perbedaan kebudayaan

3. Bentrok antar kepentingan

${ }^{17}$ Soerjono soekanto, Fungsionalisme dan teori konflik dalam perkembangan Sosiologi (Jakarta: sinar Grafika, 1980).h.79 


\section{Perubahan- perubahan sosial ${ }^{18}$}

Konflik merupakan perjuangan terhadap nilai-nilai dan tuntutantuntutan terhadap status, kekuasaan, dan sumber-sumber langka dimna tujuan dan lawan-lawan konflik adalah menetralisir, merugikan atau menyingkirkan lawan-lawan mereka.

Konflik yang berlangsung dengan kelompok luar dalam komunitas keagamaan tertentu dapat memperkuat identitas para anggota kelompok, karena konflik dapat menjalankan fungsi positif di dalam kelompoknya. Fakta menunjukan konflik dengan kelompok lain itu bisa saja mempunyai dasar yang realistis, tetapi sering juga berdasarkan atas isu yang non realistis dan bersifat laten. Coser menjelaskan,suatu konflik yang para pesertanya merasa bahwa semata-mata merupakan wakil dan kolektifitaskolektifitas atau kelompok-kelompok ,berjuang bukan untuk dirinya,tetapi hanya untuk cita-cita kelompok yang diwakilinya itu.sangat mungkin lebih radikal serta tak kenal ampun dibanding dengan bila merka berjuang hanya untuk alasan-alasan pribadi. ${ }^{19}$

Konsekuensi logis atau akibat lanjut dari hal-hal itu mudahnya muncul persaingan dan bahkan konflik secara kelompok atau antar umat beragama yang satu dengan lainnya. Peristiwa atau indikasi adanya fenomena fenomena semacam itu banyak terjadi diberbagai daerah, termasuk juga di Lampung Selatan.

Konflik berbahaya bagi masyarakat lapisan menengah dan bawah karena konflik itu dapat bersifat disfungsional, mengakibatkan perpecahan, disintegrasi dan mengacaukan masyarakat. Bagi warga masyarakat kalangan menengah dan bawah mudah terprovokasi dan perilaku mereka cenderung anarkis. Berbeda pada mereka yang berada pada lapisan atas, sebabkemampuan berpikir dan menganalisis permasalahan dapat lebih rasional dan bijaksana. Memang konflik dapat menimbulkan keadaan yang positif karena bisa mendorong perubahan masyarakat disatu pihak dan sebaliknyadapat bersifat negatif sekiranya

18 Perbedaan pendirian dan perasaan mungkin menyebabkan bentrokan antara orang perorangan, $b$. perbedaan kepribadian dari orang perorangan tergantung pula dari pola-pola kebudayaan. Yang menjadi latar belakang pembentukan dan mepengmabangan pribadi. Seorang secara sadar, sedikit banyak akan terpengaruh oleh pola-pola pemikiran dan pendirian, dari kelompok selajutnya. Selanjutnya keadaan tersebut dapat pula mengakibatkan pertentangan antar kelompok manusia, c. Bentrokan kepentingan orang perorangan maupun kelompokkelompok manusia merupakan sumber-sumber lain dari pertentangan. Kepentingan tersebut dapat bermacam-macam, misalnya kepentingan ekonomi, politik, budaya, agama dan sebagainya, d. Peruabahan sosial yang cepat dalam masyarakat untuk sementara waktu merubah nilai-nilai dalam masyarakat tadi dan menyebabkan terjadinya golongan- golongan yang berbeda pendiriannya mengenai re-organisasi dan sistem nilai yang sebagai akibat perubahannya menjadikan suatu dis- organisasi.

${ }^{19}$ Poloma, Contemporary Sociological Theory, trans. oleh Yosagama (Jakarta: Rajawali, 1984).h.121 
berkelanjutan tanpa mengambil solusi yang dianggap bermanfaat bagi semua pihak sebagai akhir dan peristiwa konflik.

Sebenernya upaya yang telah dirintis pemerintah dan para pemuka agama untuk tegaknya sendi-sendinya bangsa selama ini telah dilakukan dengan mengambangkan konsep kerukunan dan toleransi beragama melalui forum musyawarah antar umat beragama, intern pemeluk agama, dan umat beragama dengan pemerintah; dan sampai kini nasih perlu ditindak lanjuti dn sekaligus ditinjau ulang. Sebab, meski berbagai formulasi musyawarah dan dialog dikembangkan, dan berbagai organisasi dan lembaga agama didirikan, termasuk lembaga-lembaga formal keagamaan seperti :

1. Kementerian Agama (Kemenag),

2. Majelis Ulama Indonesia (MUI),

3. Persatuan Gereja Indonesia (PGI),

4. Parisahda Hindu Darma Indonesia (PHDI), dan

5. Perwakilan Umat Budha Indonesia (WALUBI).

Lembaga-lembaga tersebut kemudian dibentuk satu organisasi dibawah lingkup Kemenaga yaitu, Kerukunan Umat Beragama (KUB), serat berbagai peraturan perundang-undangan pemerintah dibentuk, ternyata belum sepenuhnya, mampu memanaje konflik-konflik sosial keagamaan dengan baik dengan tujuan dan harapan umat beragama.

Berdasarkan pada kondisi masyarakat setempat,sebenarnya ada dua komponen penting yang dapat dikembangkan jika ada peristiwa konflik. Dalam merancang penyelesaian konflik partisipatif yaitu: konsep konflik dan integrasi dengan menempatkan masing-masing komponen pada posisinyayang lebih proposional. Pertama, konflik dari intergrasi yang kedua konsep ini dapat dipergunakan secara bersamaan, yang satu menegaskan yang kedua kesulitannya masih sering dipahami, konflik dianggap sebagai pertentangan yang bersifat langsung dan disadari antara individu-individu atau kelompok-kelompok.

\section{e. Dialog Nilai-Nilai Teologis Dalam Kerukunan}

Membicarakan kerukunan antar umat beragama melalui seminar, dialog, rapat serta berbagai forum lainnya merupakan hal yang sangat penting. Sebab sama diketahui bahwa kerukunan hidup umat beragama bukan barang jadi melainkan suatu yang mesti harus dipelihara dan dirawat. Sebagaimana disadari bahwa tuhan menciptakan manusia dalam wujud yang berbeda-beda, dari segi etnis, warna kulit, budaya, agama dan sebagainya tetapi jangan dibedakan, artinya tidak dilakukan secara diskriminatif. Dan diupayakan hidup rukun dan damai. Memang ada pihak yang menganggap adanya perbedaan-perbedaan baik vertikal maupun horizontal sebagai penghalang dan berpotensi menimbulkan halhal yang tidak diinginkan. Ada pendapat yang mengungkapkan bahwa 
apabila kemajemukan, perbedaan ditangani, diselaikan dengan adil dan baik tanpa melihat latar belakang SARA, maka perbedaan ini akan menjadi satu kekuatan dalam mencapai kemajuan bersama seluruh masyarakat. Tegasnya masyarakat mesti diberi kesempatan yang sama dalam pengabdian kepada daerah dan masyarakat berdasarkan kemampuan dan prestasi dan bukan dengan pertimbangan isu SARA. Pemerintah hendaknya mengayomi semua pemeluk agama secara jujur dan tidak diskriminatif.

\section{f. Dialog Pembangunan Kualitas Keerukunan Antar Umat Beragama}

Kita tidak menghendaki terwujudnya kerukunan yang semu ataupun yang dangkal dan rapuh. Kerukunan yang hendak dicapai adalah yang kokoh dan tahan uji, kerukunan seperti ini mencerminkan 5 kualitas yaitu; religius, harmonis, denamis, kreatifitas bersama, dan produktif.

Pertama, bahwa kerukunan itu mencerminkan suasana hubungan yang religius artinya hubungan sesama umat beragama sungguh-sungguh muncul dari hati nurani yang terdalam sebagi bagian dari keberagamaan sebagai pengabdian kepada Tuhan Yang Maha Esa. Hal ini harus dihayati secara penuh, bukan mengambang lebih-lebih bila itu hanya satu kepura=puraan ini penting sekalian dan amat mendasar. Bahkan merupakan kunci bagai kemaslahatan bersama.

Kedua, bahwa kerukunan itu mencerminkan suasana hubungan yang harmonis. Artinya, hubungan yang satu dengan yang lainnya serasi. Tercermin dari adanya tenggang rasa, hormat menghormati, dan rasa kebersamaan.

Ketiga, bahwa kerukunan itu mencerminkan hubungan yang dinamis, tidak statis dan tidak pasif. Sebagai mahluk ciptaan tuhan yang termulya, tidak sepantasnya bersikap statis dan pasif satu dengan yang lainnya manusia perlu meningkatkan dinamika hubungan untuk melakukan halhal yang bermakna dan bermanfaat dalam berbagai bentuk tolong menolong dan kerja sama.

Keempat, bahwa kerukuna itu mencerminkan adanya berbagai kreatifitas bersama. Berbagai gagasan dan ide diwujudkan secara bersama. Begitu juga dengan permasalahan yang dihadapi ditanggulangi secara bersama pula. Seni dan budaya dikembangkan secara bersama pula agar hidup bermakna.

Kelima, bahwa kerukunan mencerminkan adanya kegiatan-kegiatan bersama yang produktif, sungguh-sungguh menghasilkan sesuatu yang bermanfaat bagi masyarakat umat beragam baik moril, spirituil, maupun secara material.

Keenam, kualitas kerukunan tersebut diatas bila dipahami dan dijadikan dasar "pengembangan kerukunan antar umat beragama melalui jaringan kerja sama" sebagai mana pelaksana ajarran agama yang universal, 
religius. Tegasnya hubungan vertikal dengan Tuhan dan horizontal dengan sesama manusia harus seimbang.

\section{SIMPULAN}

Dari penjabaran diatas, maka dapat disimpulkan bahwa bentukbentuk konflik yang pernah terjadi dikalangan masyarakat diantaranya;

1. Konflik Antar Umat Beragama: Pendirian rumah ibadah dan penyiaran agama, yang lebih didasarkan kepadakepentingan golongan dan kelompok;

2. Konflik Internal Umat Beragama: perbedaan faham terhadap ajaran agama dan penyimpangan dari ajaran agama yang menimbulkan keresahan dimasyarakat (aliran tertentu);

3. Konflik diluar Masala Keagamaan: perebutan tanah, perkelahian. Bentuk-bentuk konflik dalam interaksi sosial keagamaan sering berubah-ubah dari bentuk rukun (asosiatif) ke bentuk disasosiatif (tidak rukun). Selain itu, interaksi sosial baik intern umat beragama maupun antar umat beragama relatif lebih menunjukkan sifat integratif. Hanya masalah-masalah khilafiyah yang sering muncul dikalangan intern umat beragama, baik antar umat Islam sendiri maupun pada umat Kristen. Kenyataan ini tidak sampai memecah belah intern umat beragama.

4. Kinerja Kerukunan Umat Beragama (KUB) sebagai Lembaga yang konsen dalam bidang kerukunan antar umat beragama. Berprinsip bahwa keyakinan yang di anut oleh satu golongan bukan merupakan ancaman bagi golongan lainnya, tetapi merupakan sarana berkompetisi dalam kebaikan untuk meningkatkan kesejahteraan penganutnya.

5. Dialog antar Umat beragama cukup efektif dalam menanggulangi konflik. Diantaranya dialog antar umat beragama, intern umat beragama, dan antar umat beragama dengan pemerintah. Dengan dialog, kerukunan terkondisi dan mendukung pembangunan daerah, hal ini diawali dari peningkatan pemahaman ajaran agama secara utuh dan benar sejalan dengan dinamika masyarakat beragama. Pemahaman dialog dipadukan dengan model penyelesaian patisipatif baik dari aspek politik, moral, agama, ekonomi, sosial, dan budaya.

\section{DAFTAR PUSTAKA}


Adi Sasono, dan Didin Hafiduddin. Solusi Islam Atas Problem Umat (Ekonomi Pendidikan dan Dakwah). Jakarta: Gema Insani Press, 1998.

Arif Subhan. Agama dan Tantangan Zaman. Jakarta: Prisma, 1998.

Faisal Ismail. wawasan Pokok Fikiran Islam,Tentang Islam dan Umatnya. Jakarta: Raja Wali Press, t.t.

Ilyas Ba-Yunus, dan Farid Ahmad. sosiologi dan masyarakat kontemporer. Bandung: Mizan, 1993.

Imam Ahmad. “Agama Dan Tantangan Zaman." Prisma Jakarta 1084. t.t.

J.Garang. Agama dan Tantangan Zaman. Jakarta: LP3ES IKAPI, 1985.

Kementerian Agama Republik Indonesia. Al-Kamal Al-Qur'an Tajwid Warna, Transletirasi Per Kata, Terjemah Per Kata. Jakarta Pusat: Pustaka jaya Ilmu, 2016.

Muhammad Thohlan Hasan. Islam dalam perspektif sosio kultural. Jakarta: Lantabora Press, 2000.

Muhammad Tholehah Hasan. Kerukunan Hidup umat Beragama,Proyek Kerukunan Hidup Umat Beragama. Jakarta: depag RI, 1997.

Mukti Ali. Ilmu Perbandingan Agama di Indonesia. Bandung: Mizan, 1993.

Munwar Ahmad Anees, Syed Z.Abedin, dan Ziauddin Sardar. Dialog Muslim Kristen,Dulu sekarang Dan Esok. Yogyakarta: Al-Qolam, t.t.

Poloma. Contemporary Sociological Theory. Diterjemahkan oleh Yosagama. Jakarta: Rajawali, 1984.

Satrio Pinandito, trans. oleh. Islam Agama protes. Jakarta: Pustaka Hidayah, 1993.

Soerjono soekanto. Fungsionalisme dan teori konflik dalam perkembangan Sosiologi. Jakarta: sinar Grafika, 1980.

Soleman B Taneko. Konsepsi Sistem Sosial dan Sistem di Indonesia. Jakarta: Fajar Agung, 1986. 